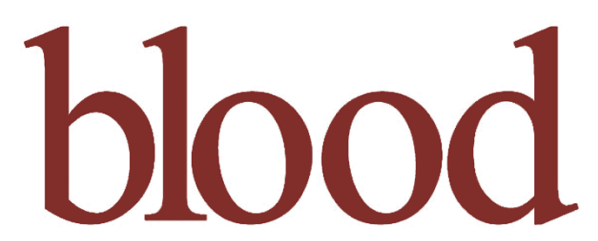

2005 106: 419-427

Prepublished online March 22, 2005;

doi:10.1182/blood-2004-09-3507

\title{
Bone marrow mesenchymal stem cells express a restricted set of functionally active chemokine receptors capable of promoting migration to pancreatic islets
}

Valeria Sordi, Maria Luisa Malosio, Federica Marchesi, Alessia Mercalli, Raffaella Melzi, Tiziana Giordano, Nathalie Belmonte, Giuliana Ferrari, Biagio Eugenio Leone, Federico Bertuzzi, Gianpaolo Zerbini, Paola Allavena, Ezio Bonifacio and Lorenzo Piemonti

Updated information and services can be found at: http://bloodjournal.hematologylibrary.org/content/106/2/419.full.html

Articles on similar topics can be found in the following Blood collections Chemokines, Cytokines, and Interleukins (564 articles)

Hematopoiesis and Stem Cells (3145 articles)

Information about reproducing this article in parts or in its entirety may be found online at: http://bloodjournal.hematologylibrary.org/site/misc/rights.xhtml\#repub_requests

Information about ordering reprints may be found online at:

http://bloodjournal.hematologylibrary.org/site/misc/rights.xhtml\#reprints

Information about subscriptions and ASH membership may be found online at: http://bloodjournal.hematologylibrary.org/site/subscriptions/index.xhtml

Blood (print ISSN 0006-4971, online ISSN 1528-0020), is published weekly by the American Society of Hematology, 2021 L St, NW, Suite 900, Washington DC 20036.

Copyright 2011 by The American Society of Hematology; all rights reserved.

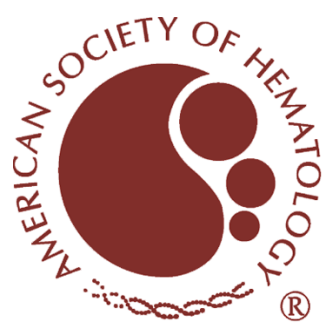




\title{
Bone marrow mesenchymal stem cells express a restricted set of functionally active chemokine receptors capable of promoting migration to pancreatic islets
}

\author{
Valeria Sordi, Maria Luisa Malosio, Federica Marchesi, Alessia Mercalli, Raffaella Melzi, Tiziana Giordano, Nathalie Belmonte, \\ Giuliana Ferrari, Biagio Eugenio Leone, Federico Bertuzzi, Gianpaolo Zerbini, Paola Allavena, Ezio Bonifacio, and Lorenzo Piemonti
}

\begin{abstract}
Bone marrow-derived mesenchymal stem cells (BM-MSCs) are stromal cells with the ability to proliferate and differentiate into many tissues. Although they represent powerful tools for several therapeutic settings, mechanisms regulating their migration to peripheral tissues are still unknown. Here, we report chemokine receptor expression on human BM-MSCs and their role in mediating migration to tissues. A minority of BM-MSCs (2\% to $25 \%$ ) expressed a restricted set of chemokine receptors (CXC receptor 4 [CXCR4], CX3C receptor 1 [CX3CR1], CXCR6, CC
\end{abstract}

chemokine receptor 1 [CCR1], CCR7) and, accordingly, showed appreciable chemotactic migration in response to the chemokines CXC ligand 12 (CXCL12), CX3CL1, CXCL16, CC chemokine ligand 3 (CCL3), and CCL19. Using human pancreatic islets as an in vitro model of peripheral tissue, we showed that islet supernatants released factors able to attract BM-MSCs in vitro, and this attraction was principally mediated by CX3CL1 and CXCL12. Moreover, cells with features of BM-MSCs were detected within the pancreatic islets of mice injected with green fluorescent protein (GFP)-positive BM. A population of bona fide MSCs that also expressed CXCR4, CXCR6, CCR1, and CCR7 could be isolated from normal adult human pancreas. This study defines the chemokine receptor repertoire of human BM-MSCs that determines their migratory activity. Modulation of homing capacity may be instrumental for harnessing the therapeutic potential of BM-MSCs. (Blood. 2005; 106:419-427)

(C) 2005 by The American Society of Hematology

\section{Introduction}

Bone marrow (BM) is a complex tissue containing hematopoietic progenitor cells and a connective-tissue network of stromal cells. Marrow stroma includes a subpopulation of undifferentiated cells that are capable of becoming one of a number of phenotypes, including bone and cartilage, tendon, muscle, fat, and marrow stromal connective tissue that supports hematopoietic cell differentiation. ${ }^{1,2}$ These cells are referred to as mesenchymal stem cells (MSCs), since they are known to have capacity of proliferation and differentiation into the mesenchymal lineage. Due to their potential for differentiation into different tissues, MSCs have emerged as a promising tool for clinical applications such as tissue engineering and cell and gene therapy. ${ }^{3-5}$

Several reports underline the ability of MSCs to migrate. ${ }^{6-13}$ MSCs are thought to migrate in the bloodstream to seed new sites of hematopoiesis and to various tissues during embryonic and fetal development. ${ }^{14,15}$ MSCs are present in large numbers in human blood from at least 7 weeks' gestation and they persist until approximately 12 weeks' gestation. ${ }^{14}$ Although circulating MSCs decrease after 12 weeks, there is evidence that a very lowfrequency population of circulating multipotent nonhematopoietic cells resembling the classical MSCs persist through to adult life. ${ }^{16-18}$ MSCs migrate efficiently to hematopoietic tissues (BM and spleen) after transplantation in some experimental animal models, ${ }^{19,20}$ whereas reports of BM homing in humans are inconsistent. $^{21-26}$ Of particular interest for tissue remodeling, intravenous delivery of MSCs results in their specific migration to a site of injury. ${ }^{6-8,10,27}$ This ability of implanted MSCs to seek out the site of tissue damage has been demonstrated in bone or cartilage fracture, ${ }^{28}$ myocardial infarction, ${ }^{8,29}$ and ischemic cerebral injury. ${ }^{6,10,11}$ Because MSCs have been shown to give rise to many tissues (such as bone, cartilage, fat, endothelia, muscle, brain, and pancreatic islet cells ${ }^{30,31}$ ), migrating MSCs may represent a source of pluripotent cells that are constantly available for the repair of damaged organs. The mechanisms that guide homing of implanted cells are unclear. In this study, we examined the role of chemokines and their receptors in the migration of human MSCs. Moreover the interaction between human pancreatic islets and MSCs was investigated as a model of tissue cross talk.

\section{Material and methods}

\section{Human bone marrow mesenchymal stem cell culture}

Human bone marrow mesenchymal stem cells (BM-MSCs) were obtained from Cambrex (Baltimore, MD). There were 3 different batches used for the study. Before use, the cells were analyzed for morphology, marker
From the Telethon-Juvenile Diabetes Research Foundation Center for $\beta$ Cell Replacement, the H. S. Raffaele-Telethon Institute for Gene Therapy (HSR-TIGET), and the Renal Pathophysiology Laboratory, Division of Medicine, San Raffaele Scientific Institute, Via Olgettina, Milan Italy; the Department of Immunology and Cell Biology, "Mario Negri" Institute, Milan, Italy; and the Department of Surgery, University of Milano-Bicocca, Milan, Italy.

Submitted September 15, 2004; accepted March 11, 2005. Prepublished online as Blood First Edition Paper, March 22, 2005; DOI 10.1182/blood2004-09-3507.

Supported by grants from Cassa di RIsparmio delle Province Lombarde
(CARIPLO), Istituto Superiore di Sanità (CS93 and CS81), and the Juvenile Diabetes Research Foundation/Telethon Italy (JT-01).

Reprints: Lorenzo Piemonti, Laboratory of Experimental Surgery, S. Raffaele Scientific Institute, Via Olgettina 60, 20132 Milan, Italy; e-mail: piemonti. lorenzo@ hsr.it.

The publication costs of this article were defrayed in part by page charge payment. Therefore, and solely to indicate this fact, this article is hereby marked "advertisement" in accordance with 18 U.S.C. section 1734. 
expression, and osteogenic differentiation. All batches used had a fibroblastlike morphology in culture, were homogeneously $\mathrm{CD} 73^{+}, \mathrm{CD} 105^{+}$, HLA $\mathrm{I}^{+}, \alpha \mathrm{V} \beta 3^{+}, \alpha \mathrm{V} \beta 5^{+}, \mathrm{CD} 34^{-}, \mathrm{CD} 45^{-}, \mathrm{CD} 117^{-}, \mathrm{CD} 31^{-}, \mathrm{HLAII}^{-}, \mathrm{CD}{ }^{-}$, $\mathrm{CD} 80^{-}, \mathrm{CD}^{-} 6^{-}$, and $\mathrm{CD} 40^{-}$, and were able to differentiate to osteoblasts. Cells were grown in $\alpha$-Minimum Essential Medium ( $\alpha$-MEM; Biochrom, Berlin, Germany) supplemented with $10 \%$ fetal bovine serum (FBS; Hyclone, Logan, UT). Cells were passaged twice prior to use by trypsinizing and subculturing at a 1:6 dilution. BM-MSCs were cultured in 6-well multiwell tissue culture plate (Falcon; Becton Dickinson, Franklin Lakes, $\mathrm{NJ}$ ), replacing medium twice a week.

\section{Isolation of tissue MSCs from human pancreas}

Primary human pancreatic tissues were obtained from the digest remaining after the isolation of islet cells from human pancreas, as previously described. ${ }^{32}$ The dense fraction recovered in the pellet and normally discarded was processed for MSC isolation. Following 2 washes in phosphate-buffered saline (PBS), the equivalent of $1 \mathrm{~mL}$ packed pellet was resuspended in $\alpha$-MEM and 10\% FBS, plated in one T75 tissue culturetreated flask (Costar, Cambridge, MA), and grown at $37^{\circ} \mathrm{C}$ in a humidified incubator at $5 \% \mathrm{CO}_{2}$. After 24 hours, the nonadherent material was removed and fresh medium added to the cells. Medium was changed every 3 days. Cells were harvested by trypsinization and either passaged for expansion purposes or subjected to analysis. MSCs derived from 3 pancreas preparations were used.

\section{Osteogenic differentiation of MSCs}

For the differentiation assay, cells were seeded following trypsinization into 6-well tissue culture-treated plates and grown to confluency. Differentiation was started by adding complete medium containing $1 \mathrm{nM}$ dexamethasone, $20 \mathrm{mM} \beta$-glycerolphosphate, and $50 \mu \mathrm{M} \mathrm{L}$-ascorbic acid 2-phosphate. After 21 days, cells were fixed in $4 \%$ paraformaldehyde and stained with a solution of $1 \%$ alizarin red. Cells were photographed under an inverted microscope (Leica DMIRB equipped with a $5 \times / 0.15$ numerical aperture objective and a Leica DC300Fx digital camera and Leica IM50 software; Leica Camera AG, Solms, Germany).

\section{Flow cytometry analysis of surface antigens}

Human BM-MSCs at passage 2 and human pancreatic MSCs at passage 4 were treated with $0.25 \%$ trypsin-EDTA (ethylenediaminetetraacetic acid), harvested, and washed twice with $\alpha$-MEM. Before staining, cells were allowed to recover expression of surface markers for 2 hours in suspension. Cell staining was performed using mouse monoclonal antibodies (mAbs) followed by fluorescein isothiocyanate (FITC)-conjugated affinitypurified, isotype-specific goat anti-mouse immunoglobulin $\mathrm{G}$ (IgG) $\mathrm{F}$ $\left(\mathrm{ab}^{\prime}\right)_{2}$ antibodies (Jackson ImmunoResearch Laboratories, West Grove, $\mathrm{PA}$ ). The following mAbs were used in this study: $\mathrm{L} 243$ ( $\operatorname{IgG}_{2 \mathrm{a}}$ anti-major histocompatibility complex [MHC] class II) from American Type Culture Collection (ATCC, Rockville, MD); BB1 (IgM, anti-CD80), BU63 ( $\operatorname{IgG}_{1}$, anti-CD86), and EA-5 ( $\operatorname{IgG}_{1}$ anti-CD40) from Ancell (Bayport, MN); AD2 (IgG $\mathrm{I}_{1}$, anti CD73) from BD PharMingen (San Diego, CA); $44716\left(\mathrm{IgG}_{2 \mathrm{~b}}\right.$ anti-CXC receptor 4 [CXCR4]), 150503 ( $\mathrm{IgG}_{2 \mathrm{a}}$ anti-CC chemokine receptor 7 [CCR7]), $53504.111\left(\mathrm{IgG}_{2 \mathrm{~b}}\right.$, anti-CCR1), $56811.111\left(\mathrm{IgG}_{2 \mathrm{~b}}\right.$, anti-CXCR6), and 166707 ( $\operatorname{IgG}_{1}$ anti-CD105) from R\&D System (Minneapolis, MN); 2A9-1 (rat $\mathrm{IgG}_{2 \mathrm{~b}}$ anti-CX3C receptor 1 [CX3CR1]) from MBL (Woburn, MA); 57A5 ( $\operatorname{IgG}_{1}$ anti-CD117) from Kamiya Biomedical Company (Seattle, WA); 581 ( $\operatorname{IgG}_{1}$ anti-CD34), H130 ( $\operatorname{IgG}_{1}$ anti-CD45), and $\mathrm{MBC} 8.2$ ( $\mathrm{IgG}_{1}$ anti-CD31) from Caltag Laboratories (Burlingame, $\mathrm{CA})$; and $\mathrm{LM} 609$ ( $\operatorname{IgG}_{1}$ anti- $\left.\alpha \mathrm{v} \beta 3\right)$ and PF16 $\left(\operatorname{IgG}_{1}\right.$ anti- $\left.\alpha \mathrm{v} \beta 5\right)$ from Chemicon (Temecula, CA). Cells were analyzed with a FACScalibur flow cytometer. Results are expressed as the mean percentage of positive cells and standard deviation from multiple experiments.

\section{Chemotaxis assay}

Cell migration was evaluated using a 48 -well modified Boyden chamber as previously described, with minor modifications. ${ }^{33}$ The polycarbonate filter (12- $\mu \mathrm{m}$ pore size, CN110416; Neuroprobe, Bethesda, MD) was precoated with fibronectin $(5 \mu \mathrm{g} / \mathrm{mL}$; Sigma Chemical, St Louis, MO); cells were resuspended at $5 \times 10^{5} / \mathrm{mL}$ in the appropriate medium supplemented with $1 \%$ FBS and seeded in the upper chamber. Recombinant CXC ligand 12 (CXCL12), CX3C ligand 1 (CX3CL1), CC chemokine ligand 3 (CCL3), CCL19 (Peprotech, Rocky Hill, NJ), and CXCL16 (R\&D System) were used as chemoattractants in the lower compartment. The chambers were incubated overnight at $37^{\circ} \mathrm{C}$. Results are expressed as the mean number of net migrated cells over control cells (basal migration without chemotactic stimulus), counted in 10 microscope fields at high-power magnification $(\times 1000)$. Each experiment was performed in triplicate. Where indicated, cells were incubated with blocking mAbs against CXCR4 (12G5, 10 $\mu \mathrm{g} / \mathrm{mL}$; R\&D System) and/or CX3CL1 (81 506, $10 \mu \mathrm{g} / \mathrm{mL}$; R\&D System).

\section{Chemokine and cytokine assays}

For MSCs, supernatant was collected after 48 hours of culture. For human pancreatic islets, supernatant was collected after 48 hours of culture in the presence or absence of interleukin- $1 \beta$ (IL- $1 \beta, 10 \mathrm{ng} / \mathrm{mL}$; R\&D System). Human islets were obtained from cadaveric donors and were isolated using a modification of the Ricordi method as previously described. ${ }^{32}$ Islets used for chemokine and migration experiments were handpicked. Chemokines and cytokines were quantified by SearchLight Human Proteoma Array (Pierce Endogen, Woburn, MA) according to the manufacturer's instructions. CX3CL1 and CCL12 were also measured by enzyme-linked immunosorbent assay (ELISA) with commercial kits (R\&D System).

\section{RT-PCR}

Total RNA was extracted with Trizol-LS reagent (Invitrogen, Carlsbad, CA). For reverse-transcriptase-polymerase chain reaction (RT-PCR), cDNA was synthesized in a $20-\mu \mathrm{L}$ reaction volume containing $4 \mu \mathrm{g}$ total RNA and SuperScript III RT (Invitrogen), according to the manufacturer's instructions. The endogenous gene glyceraldehyde-3-phosphate dehydrogenase $(G A P D H)$ was also quantified to normalize differences in the added RNA and efficiency of reverse transcription. The thermal profile for PCR with FastStartTaq (Roche Diagnostics, Penzberg, Germany) was $94^{\circ} \mathrm{C}$ for 5 minutes, followed by 35 cycles of 30 seconds at $94^{\circ} \mathrm{C}$, with 1 -minute annealing intervals $\left(57^{\circ} \mathrm{C}\right.$ for chemokine receptors) followed by 1 -minute extension at $72^{\circ} \mathrm{C}$. The PCR products were size-fractioned by electrophoresis on $2 \%$ agarose gels. The specific primers used are shown in Table 1.

\section{Animal model for BM cell migration to pancreatic islets}

BM transplantation experiments were performed using a green fluorescent protein (GFP) transgenic strain as a donor and a coisogenic strain, expressing the allelic form of CD45 antigen (CD45.1) as recipient. Murine BM cells were harvested from 7-week-old male C57BL/6-TgN(ACTbEGFP)1Osb mice (Jackson Laboratories, Bar Harbor, ME) by flushing femurs and tibiae. Per mouse, $3 \times 10^{6}$ donor BM cells were injected into the tail vein of recipient 7-week-old C57BL/6-CD45.1 mice (B/6.SJL-CD45 a-Pep ${ }^{3 b}$; Jackson Laboratories), lethally irradiated with a dose of $975 \mathrm{cGy}$. Mice were killed 2 to 13 weeks after BM transplantation, hematopoietic tissues (BM, spleen, and thymus) were collected for flow cytometry analysis, and pancreata were isolated for immunohistochemistry and in vitro cultures. All the described experiments were approved by the Institute's Animal Care and Use Committee.

\section{Immunofluorescence and immunohistochemistry}

For tissue section analysis, animals were anesthetized and perfused intracardially with $4 \%$ paraformaldehyde/PBS. Perfused pancreata were dissected and further fixed in $4 \%$ paraformaldehyde at $4^{\circ} \mathrm{C}$ for one hour. Fixed organs were washed with PBS, cryoprotected by incubation in increasing concentration of cold sucrose $(10 \%, 20 \%$, and $30 \%$; total 12-24 hours), and quick-frozen in cryoembedding compound (Microm International, Walldorf, Germany). For intrinsic GFP analysis, $10-\mu \mathrm{m}$ frozen sections were cut from several distinct lobes and mounted using VECTASHIELD with 4', 6-diamidino-2-phenylindole (DAPI; Vector Laboratories, Burlingame, CA). Double immunohistochemical staining on $10-\mu \mathrm{m}$ frozen pancreatic sections was performed with a polyclonal guinea pig anti-insulin (DAKO, Carpinteria, CA) and a polyclonal rabbit antiglucagon 
From bloodjournal.hematologylibrary.org at BIBLIOTECA POLO SAN PAOLO on July 23, 2013. For personal use only.

Table 1. Primers used for chemokine receptor detection

\begin{tabular}{|c|c|c|}
\hline Gene & Oligonucleotide forward & Oligonucleotide reverse \\
\hline Insulin & 5'CTTTGTGAACCAACACCTGTG $3^{\prime}$ & 5'GTTGCAGTAGTTCTCCAGTG $3^{\prime}$ \\
\hline Cxcr1 & 5'GGCTGCTGGGGACTGTCTATGAAT $3^{\prime}$ & 5'GCCCGGCCGATGTTGTTG 3' \\
\hline Cxcr2 & 5'CCGCCCCATGTGAACCAGAA $3^{\prime}$ & 5'AGGGCCAGGAGCAAGGACAGAC $3^{\prime}$ \\
\hline Cxcr3 & $5^{\prime}$ CAACGCCACCCACTGCCAATACAA $3^{\prime}$ & $5^{\prime}$ CAGGCGCAAGAGCAGCATCCACA $3^{\prime}$ \\
\hline Cxcr4 & 5'AGCTGTTGGCTGAAAAGGTGGTCTATG $3^{\prime}$ & 5'GCGCTTCTGGTGGCCCTTGGAGTGTG 3 ' \\
\hline Cxcr5 & 5'AACTACCCGCTAACGCTGGAAATGGAC $3^{\prime}$ & $5^{\prime}$ CACGGCAAAGGGCAAGATGAAGACC $3^{\prime}$ \\
\hline Cxcr6 & 5'ATGGCAATGTCTTTAATCTCGACAA 3' & 5'TGAAAGCTGGTCATGGCATAGTATT $3^{\prime}$ \\
\hline Cor1 & 5'CAACTCCGTGCCAGAAGGTGAA $3^{\prime}$ & 5'GCCAGGGCCCAAATGATGAT $3^{\prime}$ \\
\hline Ccr2 & 5'CCAACGAGAGCGGTGAAGAAGTC $3^{\prime}$ & 5'TCCGCCAAAATAACCGATGTGAT 3' \\
\hline Ccr3 & 5'GAGCCCGGACTGTCACTTTTG 3' & 5'CAGATGCTTGCTCCGCTCACAG 3' \\
\hline Cor4 & 5'AAGAAGAACAAGGCGGTGAAGATG $3^{\prime}$ & 5'AGGCCCCTGCAGGTTTTGAAG 3' \\
\hline Ccr5 & 5'CTGGCCATCTCTGACCTGTTTTTC $3^{\prime}$ & 5'СAGCCCTGTGCCTCTTCTTCTCAT 3' \\
\hline Ccr6 & 5'CCTGGGGAATATTCTGGTGGTGA $3^{\prime}$ & 5'CATCGCTGCCTTGGGTGTTGTAT $3^{\prime}$ \\
\hline Ccr7 & 5'GTGCCCGCGTCCTTCTCATCAG 3' & 5'GGCCAGGACCACCCCATTGTAG 3' \\
\hline Ccr8 & 5'GGCCCTGTCTGACCTGCTTTTT $3^{\prime}$ & 5'ATGGCCTTGGTCTTGTTGTGGTT $3^{\prime}$ \\
\hline Ccr9 & 5'CACTGTCCTGACCGTCTTTGTCT 3' & 5'СTTCAAGCTTCCСTCTCTCCTTG 3' \\
\hline Cor10 & 5'TGCTGGATACTGCCGATCTACTG $3^{\prime}$ & 5'TCTAGATTCGCAGCCCTAGTTGTC $3^{\prime}$ \\
\hline Xcr1 & $5^{\prime}$ TGACCATCCACCGCTACC $3^{\prime}$ & 5'ATCTGGGTCCGAAACAGC 3' \\
\hline Cx3cr1 & 5'TCCTTCTGGTGGTCATCG 3' & 5'TGTGCATTGGGTCCATCA $3^{\prime}$ \\
\hline GADPDH & $5^{\prime}$ GCCAAGGTCATCCATGACAACTTTGG $3^{\prime}$ & 5'GCCTGCTTCACCACCTTCTTGATGTC $3^{\prime}$ \\
\hline
\end{tabular}

(DAKO) antisera using a standard protocol. AffiniPure anti-guinea pig tetramethylrhodamine-5(and 6)-isothiocyanate (TRITC) and anti-rabbit cyanin 5 (Cy5) secondary antibodies (Jackson ImmunoResearch Laboratories) were used for detection. Tissue sections were counterstained with DAPI prior to mounting.

For ex vivo analysis of islets, animals were killed and pancreata were removed immediately. Islets were isolated as previously described ${ }^{34}$ and kept in culture in RPMI containing 10\% FBS in 6-well plates for the appropriate times or plated on poly-L-lys-coated coverslips for immunofluorescence staining. A Leica TCS SP2 AOBS confocal scanning microscope equipped with a $\times 63$ oil immersion objective (numerical aperture 1.4) was used to image the results. Adobe Photoshop v.5.02 (Adobe, San Jose, CA) was used to visualize the images and to compose the final pictures.

\section{Results}

\section{Expression of chemokine receptors and chemokines in BM-MSCs}

$\mathrm{CC}, \mathrm{CXC}, \mathrm{CX} 3 \mathrm{C}$, and $\mathrm{C}$ chemokine receptor expression on BM-MSCs was examined in order to determine potential migratory stimuli. BM-MSCs expressed the transcripts for CCR1, CCR7, CXCR4, CXCR6, and CX3CR1 (Figure 1A). Transcripts for other chemokine receptors were not detected. Protein expression was determined by fluorescence-activated cell sorter (FACS) analysis (Figure 1B). The expression of chemokine receptors appeared heterogeneous. A small percentage of cells was positive for CCR1 and CCR7 (1.8 $\pm 2.7 \%$ and $2 \pm 2.4 \%$, respectively; $\mathrm{n}=5)$, and a higher percentage of cells, but not all cells, was positive for CXCR6, CX3CR1, and CXCR4 (respectively $22 \pm 5 \%, 20 \pm 9 \%$, and $26 \pm 2.4 \% ; \mathrm{n}=5$ ).

BM-MSCs secrete several hematopoietic cytokines supporting the growth of hematopoietic progenitors. ${ }^{1,2} \mathrm{We}$ therefore tested if they can produce chemokines that are known to bind to the BM-MSC chemokine receptors and therefore able to act in an autocrine manner. BM-MSCs were cultured for 7 days. High amounts of CXCL8, CXCL12, CCL2, CCL5, and vascular endothelial growth factor (VEGF) and a low amount of CCL3 and angiopoietin 2 were detected in the culture supernatant (Figure 2A). BM-MSCs, therefore, not only express chemokine receptors but also are able to secrete some chemokines that can act in an autocrine loop (ie, CXCL12-CXCR4).

\section{BM-MSCs migrate in response to specific chemokine gradients}

The ability of BM-MSCs to migrate in response to chemotactic signals was investigated using a micromultiwell chemotaxis chamber assay. The following ligand-receptor combinations were investigated: CX3CL1 (fractalkine) for CX3CR1; CCL3 (macrophage inflammatory protein $1 \alpha[\mathrm{MIP} 1 \alpha]$ ) for CCR1; CCL19 (MIP3 $\beta$ ) and CCL21 (secondary lymphoid-tissue chemokine [SLC]) for CCR7; CXCL12 (stromal-derived factor $1 \beta$ [SDF1 $\beta]$ ) for CXCR4; and CXCL16 for CXCR6. BM-MSCs migrated in a dosedependent manner to different concentrations of CXCL12, CX ${ }_{3}$ CL1, CXCL16, CCL3, CCL19, and CCL21 (Figure 2B). Pretreatment of BM-MSCs with a blocking anti-CXCR4 mAb $(10 \mu \mathrm{g} / \mathrm{mL})$ or with anti-CX3CL1 $\mathrm{mAb}(10 \mu \mathrm{g} / \mathrm{mL})$ abrogated cell migration in response to CXCL12 and CX3CL1, respectively, confirming the specificity of the migration (data not shown).

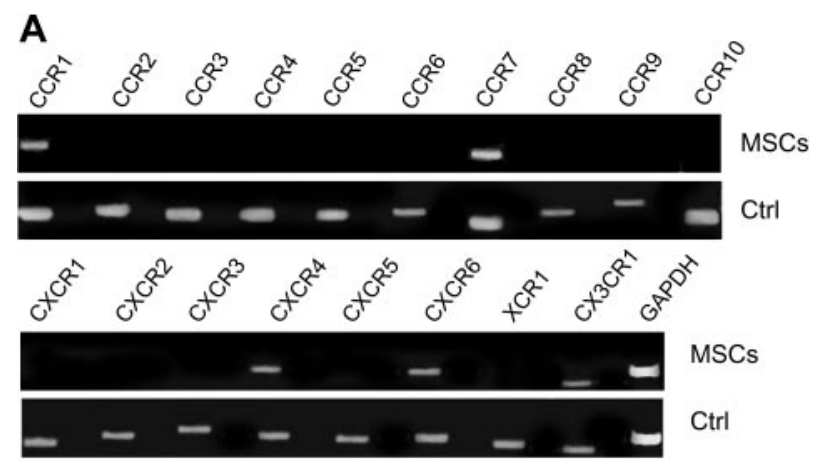

B

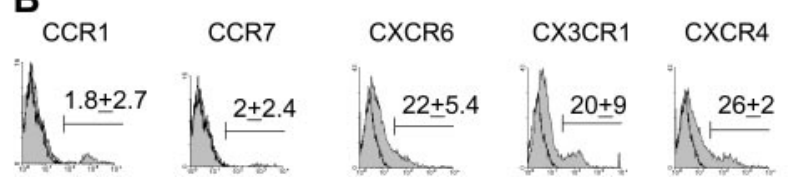

Figure 1. BM-MSCs express chemokine receptors. (A) RT-PCR expression of chemokine receptor mRNA in BM-MSCs. Human activated peripheral blood mononuclear cells (PBMCs) or splenocytes were used as positive controls (Ctrl). (B) Surface expression of CCR1, CCR7, CXCR6, CX3CR1, and CXCR4 on BM-MSCs detected by flow cytometry. A representative experiment of 5 is shown. The mean \pm SD percentage of positive cells is indicated $(n=5)$. Open curves refer to control antibody signal; shaded curves refer to specific antibody signal. 

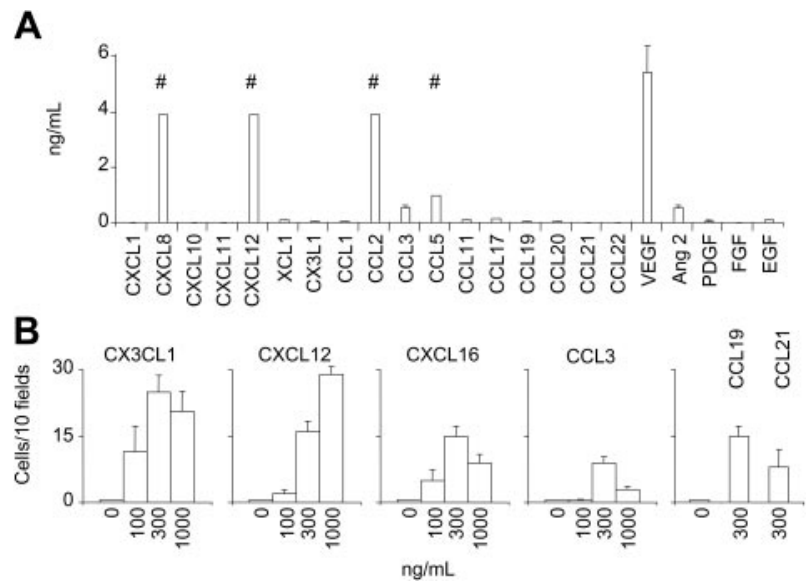

Figure 2. BM-MSCs produce chemokines and chemokines stimulate BM-MSC chemotaxis. (A) Chemokine/growth factor concentrations in supernatants from $2 \times 10^{5}$ BM-MSCs cultured in $3 \mathrm{~mL}$ medium for 7 days. Results are expressed as mean $\pm S D(n=3)$. \# indicates upper range of measurement $(4 \mathrm{ng} / \mathrm{mL}$ for CXCL8, CXCL12, CCL2; $1 \mathrm{ng} / \mathrm{mL}$ for CCL5). (B) Migration of BM-MSCs to different concentrations of CX3CL1, CXCL12, CXCL16, CCL3, CCL19, and CCL21 in a chemotaxis assay. Shown are numbers of migrated cells counted in 10 high-power fields (HPFs) after subtraction of the basal migration observed in the absence of chemokine. Basal migration was $10 \pm 5$ cells $/ 10$ HPFs $\left({ }^{*} P<.05\right.$ versus control). Values are the mean \pm SE of 8 replicates. Results are from 1 experiment of 3 performed.

\section{Pancreatic islets secrete chemokines that attract BM-MSCs}

Several recent in vivo studies ${ }^{35-37}$ demonstrated that $\mathrm{BM}$ can contribute to pancreatic $\beta$ cell regeneration, ${ }^{36}$ and mesenchymal stem cells were proposed as the BM cell type responsible for pancreatic endocrine differentiation. ${ }^{38,39}$ We therefore studied pancreatic islets for their ability to secrete chemokines and attract BM-MSCs.

Chemokine concentrations were measured in the supernatants of 3 primary cultures of human pancreatic islets. There were 100 human islets purified by handpicking and cultured for 48 hours in the presence or absence of IL-1 $\beta(10 \mathrm{ng} / \mathrm{mL})$. Chemokine release was evaluated by search light proteoma array and ELISA. High amounts of CCL2, CXCL1, CXCL8, and CXCL12, and less of CX3CL1, CCL3, and CCL20 were detected in the culture medium (Figure 3A). Since BM-MSCs express the receptors for CX3CL1 and CXCL12, these 2 factors were studied further. Human islets released CXCL12 and CX3CL1 in a time-dependent manner (Figure 3B). Whole pancreas sections from surgical specimens (tumor, $\mathrm{n}=3$; pancreas from explanted organs, $\mathrm{n}=2$ ) were examined for CXCL12 and CX3CL1 protein expression by immunohistochemistry. Both CXCL12 and CX3CL1 were visualized within the cytoplasm of islet cells. A less intensive staining was seen in ductal cells (in particular, small ducts), whereas the exocrine tissue appeared negative.

To investigate the ability of human pancreatic islets to attract BM-MSCs, we tested islet supernatants as chemoattractants for BM-MSCs in vitro. Islet supernatants were able to attract human BM-MSCs in a classical chemotaxis assay (Figure 3C). Supernatants from 4 islet preparations induced migration of $39 \pm 6$, $38 \pm 4,35 \pm 4$, and $38 \pm 5$ BM-MSCs/10 HPFs. The chemotactic activity decreased after supernatant dilution showing a dose dependency. Addition of $10 \mathrm{ng} / \mathrm{mL}$ IL- $\beta$ to islet cultures did not increase migration of BM-MSCs.

To investigate whether CXCL12 and CX3CL1 were responsible for the chemotactic activity of islet supernatants, abrogation of BM-MSC migration was sought using specific blocking antibodies
(Figure 3D). Migration of BM-MSCs was inhibited by pretreatment with blocking anti-CXCR4 mAb or anti-CX3CL1 mAb, and this inhibition was even more pronounced when both antibodies were added. These data indicate that CXCL12 and CX3CL1 are the major chemokines for BM-MSC migration found in the supernatant of human pancreatic islets.

\section{BM-derived cells migrate to islets in an in vivo experimental model}

To investigate the ability of pancreatic islets to attract BM-MSCs in vivo, we analyzed the islet recruitment of $\mathrm{BM}$ cells in a model of $\mathrm{BM}$ transplantation (BMT). Total BM cells from donor $\mathrm{GFP}^{+}$ transgenic mice (C57BL/6-TgN(ACTbEGFP)1Osb), which express GFP in all the nucleated cells, were transplanted into lethally irradiated coisogenic recipient C57BL/6-CD45.1. Animals were killed 2 to 13 weeks after transplantation, and the hematopoietic cell populations were analyzed by flow cytometry for donor chimerism. All mice that underwent transplantation showed a high level of BM chimerism, scored as CD45.2 $/$ CD $45.2^{+}+\mathrm{CD} 45.1^{+}$ ratio (mean $92 \pm 6.5 \%, 89 \pm 10 \%$, and $93 \pm 4 \%$, respectively, for mice killed at 11, 12, and 13 weeks after BMT) (data not shown). Analysis of pancreatic sections obtained 2 weeks after BMT showed that $\mathrm{GFP}^{+} \mathrm{BM}$ graft-derived cells localized around and inside the islets (Figure 4A). In separate experiments, islets were isolated 11 weeks $(n=5), 12$ weeks $(n=5)$, or 13 weeks $(n=5)$ after BMT and $\mathrm{GFP}^{+}$cells were counted. The isolated pancreatic islets of all animals contained donor-derived $\mathrm{GFP}^{+}$cells (Figure 4B-C).

Isolated islets were cultured in standard conditions for 4 weeks. Starting from day 2, the number of $\mathrm{GFP}^{+}$cells inside the islets increased, and a heterogeneous population of $\mathrm{GFP}^{+}$cells ranging from narrow spindle shaped to large polygonal cells colonized the culture dishes and proliferated (Figure 5A). Marked expansion of $\mathrm{GFP}^{+}$cells was observed during the first week for all islet cultures. Further expansion after 1 week was observed for islets isolated 13 weeks after BMT. Most $\mathrm{GFP}^{+} \mathrm{BM}$ cells obtained from islets showed a fibroblast-like morphology and did not costain with an antibody against CD45 but were positive for stem cell antigen 1 (Sca-1) (after 1 week of culture $35 \pm 5 \%$ of the $\mathrm{GFP}^{+}$cells were $\mathrm{Sca}-1^{+}, 13 \pm 4 \%$ of the $\mathrm{GFP}^{+}$were $\mathrm{CD}^{+} 5^{+}$), indicating that $\mathrm{CD} 45^{-} / \mathrm{Sca}-1^{+} \mathrm{BM}$ cells were recruited to islets in vivo, and that these cells were able to survive and proliferate after islet isolation (Figures 5B,6A). To unequivocally demonstrate that the $\mathrm{GFP}^{+}$cells obtained from islet are MSCs, we tested their ability to differentiate along the osteoblastic lineage (Figure 6B). After 3 weeks of culture under standard conditions for osteogenesis, $65 \pm 20 \%$ (mean of 10 fields) of the $\mathrm{GFP}^{+}$cells stained positive for the osteoblast marker alizarin red. Most, but not all, of the alizarin red-positive cells appeared $\mathrm{GFP}^{+}(75+15 \%)$, showing that donor BM-derived MSCs were the major but not the unique source of islet-derived cells able to differentiate along an osteoblastic lineage.

\section{Tissue MSCs resembling BM-MSCs can be isolated from human pancreas}

Using the physical property of plastic adherence with a similar methodology to that originally used by Friedenstein ${ }^{40}$ and Goshima et $\mathrm{al},{ }^{41}$ we were able to isolate a population of bona fide MSCs from human adult pancreas. Briefly, the digest remaining after the isolation of islet cells from human pancreas was kept in culture. After 1 to 3 days, the nonadherent tissue was removed with a medium change, and the adherent, or residual, cells were expanded 
A

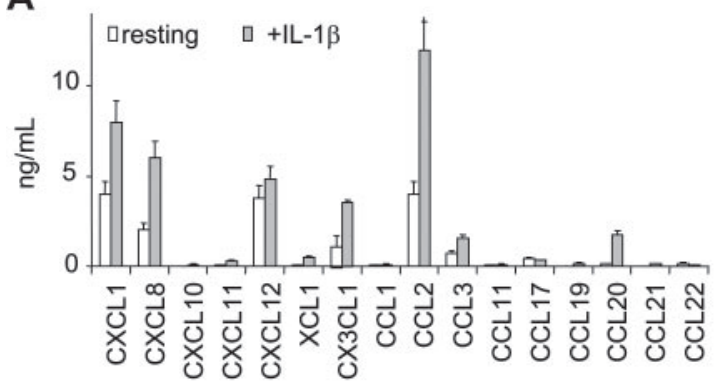

B

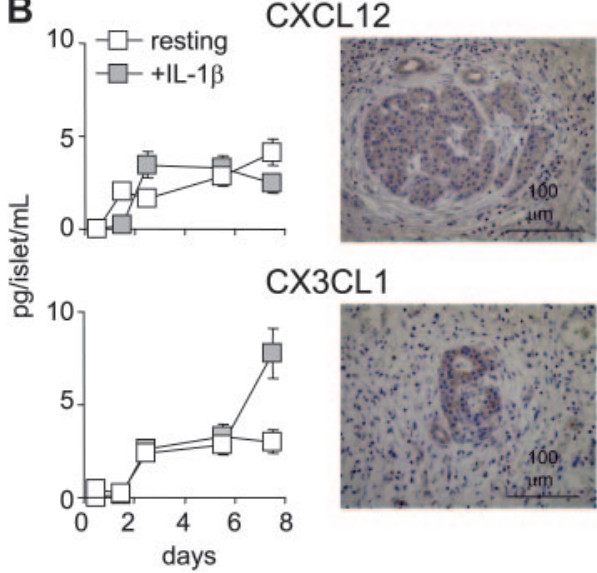

C

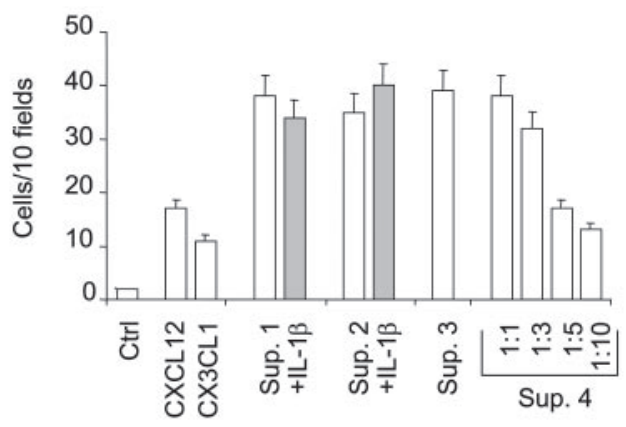

D

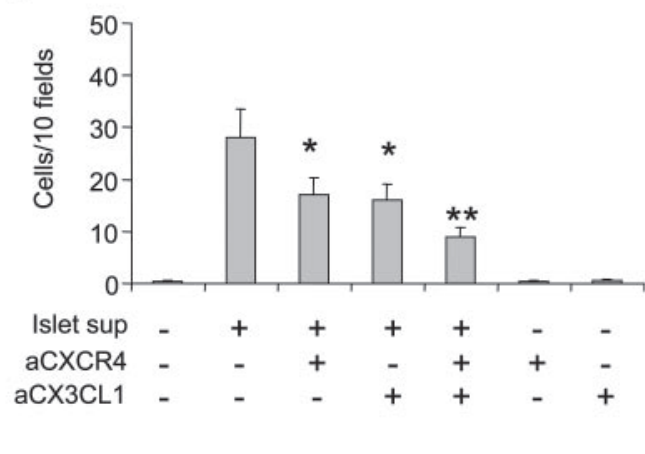

Figure 3. Human islets produce chemokines and attract BM-MSCs by secreting CXCL12 and CX3CL1. (A) Chemokines/growth factors measured in the supernatant of 100 handpicked human pancreatic islets after 48 hours of culture in the presence or absence of IL-1 $\beta$ (10 ng/mL). Results are expressed as mean $\pm \mathrm{SD}$ from 3 experiments. (B, left) Release of CXCL12 and CX3CL1 from human pancreatic islet preparation cultured in the presence or absence of IL-1 3 (10 $\mathrm{ng} / \mathrm{mL}$ ) for up to $8 \mathrm{days}$. Results are the mean \pm SD from 6 islet preparations. (Right) Immunohistochemical detection of CXCL12 and CX3CL1 in human pancreas sections. Anti-CXCL12 and anti-CX3CL1 antibodies stained

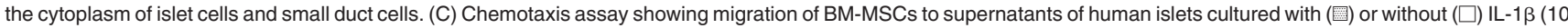
$\mathrm{ng} / \mathrm{mL}$ ). The mean \pm SE of 8 replicates is shown for each of 4 islet supernatants (Sup. 1 to 4 ). The effect of supernatant dilution on the chemotactic activity is shown for supernatant 4. Chemotaxis is measured as the number of migrated cells counted in 10 HPFs after subtraction of the basal migration observed in the absence of chemokine. Basal migration was $10 \pm 5$ cells/10 HPFs. The migration to recombinant CXCL12 and CX3CL1 is shown for comparison. (D) Inhibition studies of BM-MSC migration to islet supernatant. Supernatants were preincubated with $10 \mu \mathrm{g} / \mathrm{mL}$ anti-CX3CL1, BM-MSCs were preincubated with $10 \mu \mathrm{g} / \mathrm{mL}$ anti-CXCR4, or both conditions were observed. Chemotaxis is measured as the number of migrated cells counted in $10 \mathrm{HPFs}$ after subtraction of the basal migration observed in the absence of chemokine. Basal migration was $8+4$ cells $/ 10$ HPFs. Values are the mean \pm SE of 8 replicates. ${ }^{*} P<.02$ versus islet supernatant; ${ }^{* \star} P<.001$ versus islet supernatant.

for up to 4 weeks with additional media changes every 2 to 3 days. After 3 weeks, most, if not all, adherent cells were in monolayer. The population appeared quite homogenous with a fibroblast-like morphology resembling BM-MSCs (Figure 7B). Phenotypically, these cells expressed the markers of MSCs. They were $\mathrm{CD}^{+}{ }^{+}$(Src homology 3 [SH3] or SH4), $\mathrm{CD} 105^{+}(\mathrm{SH} 2), \alpha \mathrm{V} / \beta 3^{+}, \alpha \mathrm{V} / \beta 5^{+}$, $\mathrm{CD}^{-} 5^{-}, \mathrm{CD}_{4}^{-}, \mathrm{CD}^{-} 1^{-}$, and CD117 ${ }^{-}$(Figure 7A). Moreover they maintained the ability to proliferate in culture even after 9 months of culture. To identify these cells unequivocally as MSCs, we induced their differentiation into bone in vitro. After culture under
Figure 4. Pancreatic islets are able to attract BM-derived cells. (A) Confocal microscopy analysis of $\mathrm{GFP}^{+} \mathrm{BM}$-derived cells in pancreas 2 weeks after BMT. GFP ${ }^{+}$BM cells localized around and at lower extent inside the islet. Immunostaining for insulin (red) and glucagons (blue). DAPI: nuclear staining (Aii-iii) Close-up view of the region marked in panel Ai. White arrows point to the $\mathrm{GFP}^{+}$cells localized around the islet that are confirmed by the nuclear staining. (B-C) Islet isolated from mice that underwent transplantation with $\mathrm{GFP}^{+} \mathrm{BM}$ after 11 (exp 1), $12(\exp 2)$, and 13 weeks (exp 3). (B) Low-power magnification $(\times 5)$ of islet representative of the 3 experiments; left panel: phase contrast image; right panel: fluorescence image. (C) $\mathrm{GFP}^{+}$cells inside the islets were counted directly in floating isolated islets. Data are expressed as number of $\mathrm{GFP}^{+}$cells/islet (mean $\pm \mathrm{SE}$ ); 150 islets were evaluated for each experiment.
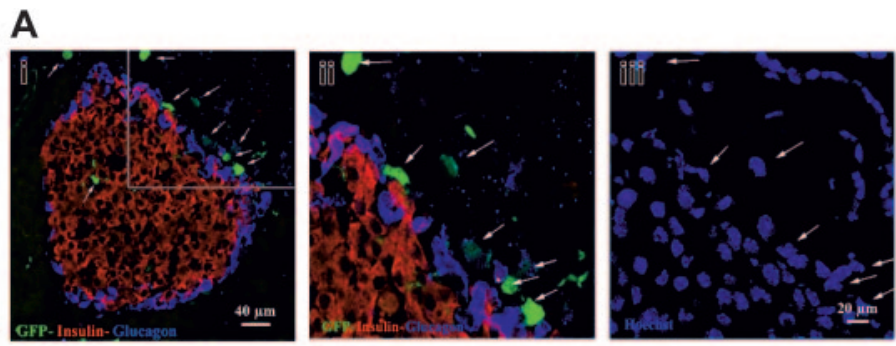

B

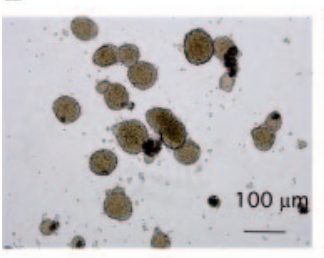

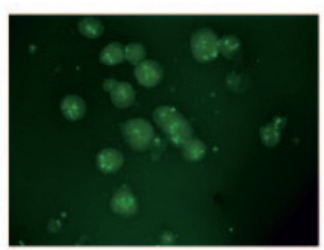

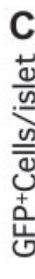

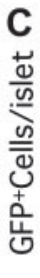

$\operatorname{Exp} 1 \operatorname{Exp} 2 \operatorname{Exp} 3$ 
A

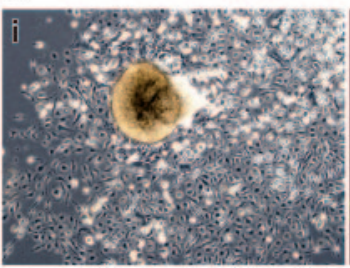

iii

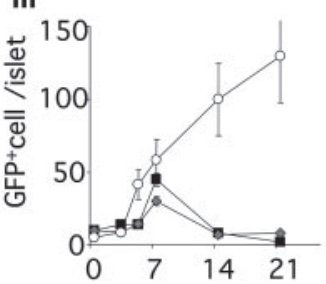

Days of culture

B
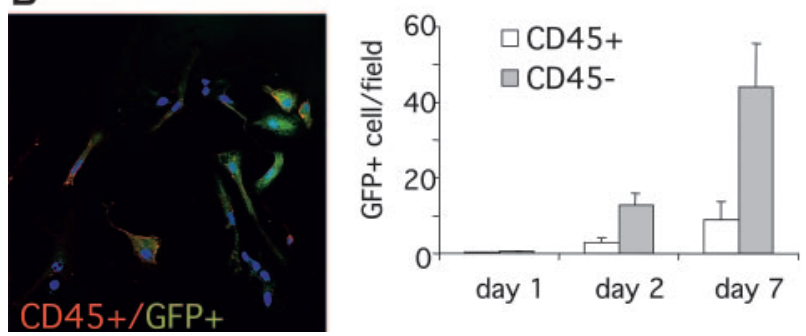

day 1 day 2 day 7

Figure 5. BM-derived $\mathrm{CD} 45^{-}$can be isolated and expanded from pancreatic islets. (A) $\mathrm{GFP}^{+}$cells inside and outside islets after islet isolation and 4 weeks of culture. Low-power magnification of islets representative of the 3 experiments photographed under an inverted microscope after 1 week of culture. (i) Phase contrast. (ii) Fluorescence image. Islets were photographed under an inverted microscope at different time points during culture. The number of $\mathrm{GFP}^{+}$cells was calculated with Scion Imaging Software (Scion, Frederick, MD) (iii-iv). For cells found inside islets (iii), data at each time point are expressed as the mean \pm SE GFP ${ }^{+}$ cell/islet determined for 100 islets. For cells found outside islets (iv), an area from the islet center corresponding to twice the islet diameter was outlined and cells scored in the area not occupied by the islet. The data at each time point are expressed as the mean $\pm \mathrm{SE} \mathrm{GFP}^{+}$cell/100 $\mu \mathrm{m}^{2}$ non-islet area determined for 50 islets. (B) Staining for CD45 (red) and GFP (green) of cells found outside isolated islets after 24 hours or 48 hours of culture. (Left) Confocal microscopy showing $\mathrm{GFP}^{+} / \mathrm{CD} 45^{+}$and $\mathrm{GFP}^{+} /$ $\mathrm{CD} 45^{-}$cells at 24 hours. (Right) Results (mean $\pm \mathrm{SE}$ ) of cell counting are expressed as number of cells/field. At least 20 fields for each time point were counted.

standard conditions for osteogenesis, they produced proteoglycanrich bone nodules that stained positive by alizarin red (Figure 7C). In FACS analysis, the expression of chemokine receptors appeared heterogeneous also in the tissue MSC populations but with some differences compared with BM-MSCs (Figure 7D). The expression of CXCR6 and CXCR4 was similar between pancreas-derived MSCs and BM-MSCs, whereas the percentage of $\mathrm{CCR}^{+}$and $\mathrm{CCR}^{+}$was significantly higher in tissue MSCs than BM-MSCs, and CX3CR1 was expressed in a very low fraction of pancreasderived MSCs (Figure 7E).

\section{Discussion}

The comprehension of the mechanism that regulates migration is crucial to the success of any clinical strategy involving MSCs. Here, we report the first detailed study to address the chemotactic responsiveness of MSCs to chemokines. BM-MSCs released chemokines and displayed a restricted response pattern to chemokines. They migrated appreciably in response to CXCL12, CX3CL1,

CXCL16, CCL3, CCL19, and CCL21, and consistent with this they expressed CXCR4, CX3CR1, CXCR6, CCR1, and CCR7. Moreover, using human pancreatic islets as in vitro and in vivo models, we showed that tissue is able to attract BM-MSCs, and this attraction in vitro is principally mediated by CX3CL1-CX3CR1 and CXCL12-CXCR4. Finally we were able to isolate a population of bona fide MSCs from adult human pancreas that displayed a distinct but overlapping pattern of chemokine receptor expression.

The current study examined isolated human BM-MSCs and human pancreatic islets in vitro. The data give conclusive evidence that BM-MSCs can migrate to specific chemokine gradients and to tissue-released chemokines. Although human BM-MSCs are known to migrate in vivo, it cannot be excluded that the in vitro findings may be influenced by culture or BM-MSC manipulation. ${ }^{19,20}$ Among the culture conditions that could affect these findings, the appreciable chemokine release by BM-MSCs is likely to negatively affect migration in vitro. Despite these limitations, the findings indicate that there is more than one migratory stimulus for BM-MSCs, that such stimuli are readily found in certain differentiated extrahematopoietic tissues, and, therefore, that BM-MSCs can be mobilized to tissue either naturally or induced to migrate to tissue. Moreover, the observations in the mouse indicate that BM-MSCs can be mobilized to inflamed nonhematopoietic tissues also in vivo. Although the mouse studies demonstrated that the BM cells migrating to pancreatic islets were $\mathrm{CD} 45^{-}$and had typical characteristics of MSCs, which that included the capacity to differentiate along an osteoblastic lineage, they were not performed using a lineage-specific model of BM transplant, and therefore cannot exclude that these $\mathrm{GFP}^{+} \mathrm{CD} 45^{-}$cells did not derive from bone marrow precursors other than bona fide BM-MSCs, including CD $45^{+}$stem cells. ${ }^{42}$ The presence of a small percentage of $\mathrm{GFP}^{+} \mathrm{CD}_{4} 5^{+}$cells and of $\mathrm{GFP}^{+}$cells unable to differentiate along the osteoblastic lineage also suggests that a proportion of $\mathrm{GFP}^{+}$ cells found in pancreatic islets was derived from non-mesenchymal stem cell sources found in the bone marrow such as macrophages and endothelial cells. Moreover, the in vivo experiments did
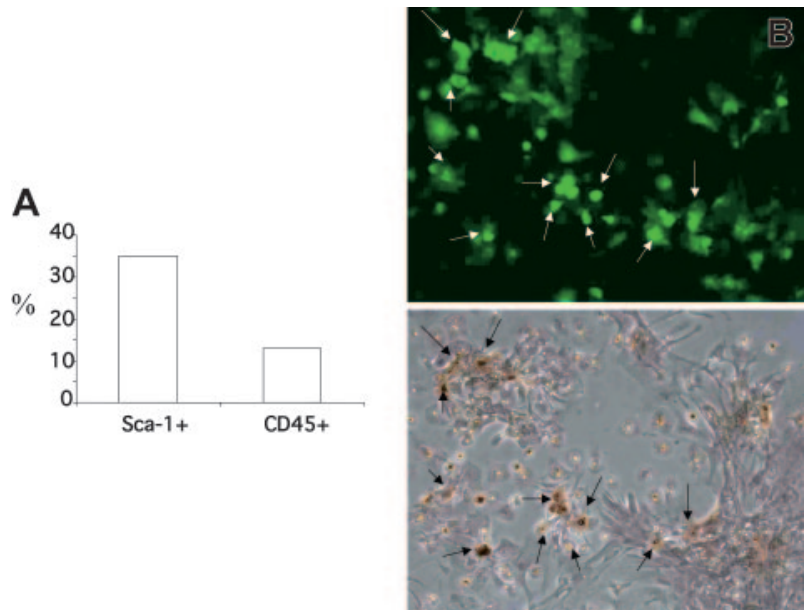

Figure 6. BM-derived $\mathrm{CD}^{-} 5^{-}$can be isolated and expanded from pancreatic islets. (A) Staining for Sca-1 and GFP of cells found outside isolated islets after 7 days of culture. Results (mean) of cell counting are expressed as percent of the GFP ${ }^{+}$ cells. (B) Alizarin red staining for detecting osteogenic differentiation of BM-derived $\mathrm{GFP}^{+}$cells isolated and expanded from pancreatic islet. Isolated islets were cultured in standard conditions for 1 week, and after 3 weeks of osteogenesis conditions were stained by alizarin red. A representative field photographed under an inverted microscope. (Top) Fluorescence image. (Bottom) Phase contrast. The arrows point to the $\mathrm{GFP}^{+}$cells localized around the islet that are confirmed to be osteoblasts by alizarin red. 
A

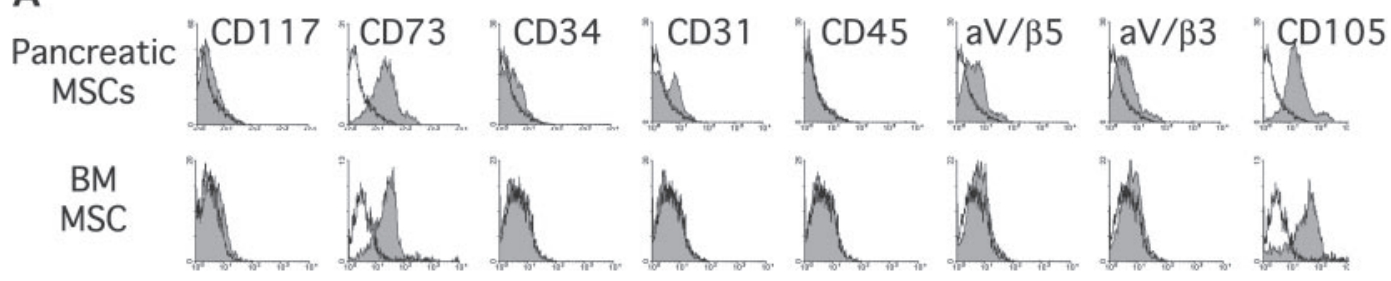

B

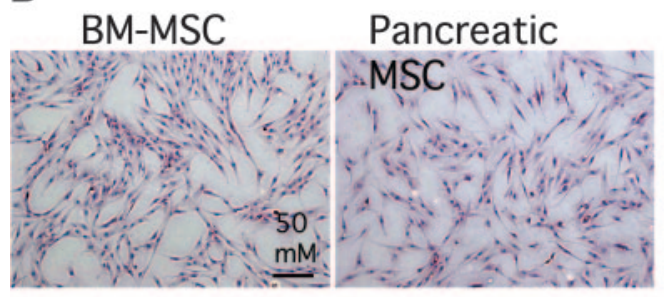

D

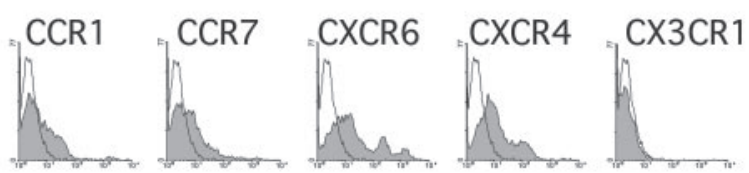

C
Pancreatic MSC differentiation

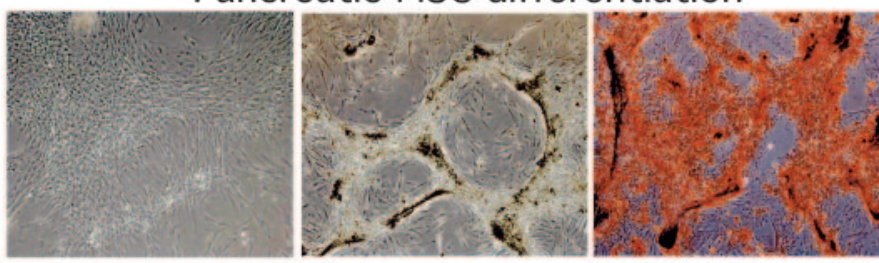

E

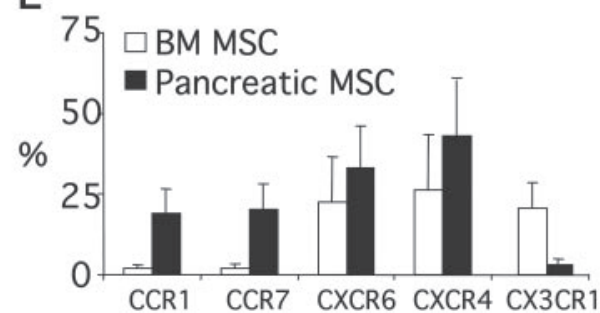

Figure 7. Characterization of tissue pancreatic MSCs. (A) Surface marker profile of pancreatic MSCs after 3 weeks of culture (top row) and BM-MSCs (bottom row). Open curves refer to control antibody signal; shaded curves refer to specific antibody signal. Results are from 1 experiment of 3 performed. (B) Morphology of BM-MSCs and tissue pancreatic MSCs. Both MSCs appeared adherent in monolayer with a fibroblast-like morphology. (C) Osteogenic differentiation of tissue pancreatic MSCs ("Materials and methods"). Tissue pancreatic MSCs in culture without differentiation medium (left) and with differentiation medium (middle and right). After differentiation, cells stained positive for alizarin red (right). (D) Surface expression of CCR1, CCR7, CXCR4, CXCR6, and CX3CR1 on tissue pancreatic MSCs detected by flow cytometry. (E) The percentage of positive cells for the chemokine receptors is reported (mean $\pm S D ; n=2$ ) and compared with the values obtained for BM-MSCs.

not investigate the signals that determine migration to the inflamed tissue.

Our findings confirm that CXCL12-CXCR4 are involved in MSC migration and this is conserved also in tissue MSCs. CXCL12 and its ligand CXCR4 play an important role in homing as shown by studies on engraftment of hematopoietic stem/ progenitor cells ${ }^{43}$ and on colonization of bone and bone marrow by metastatic breast and prostate cancer cells. ${ }^{44}$ CXCR4 was also recently reported to promote MSC migration to bone marrow. ${ }^{45}$ Moreover, the study of the expression of CXCL12 and CXCR4 from gastrulation to organogenesis in the mouse embryo provides evidence of the continuous involvement of the CXCL12-CXCR4 axis during embriogenesis. ${ }^{46}$ The CXCL12-deficient mouse and the corresponding CXCR4 mutants are the only known chemokine/ chemokine receptor mutants that display embryonic lethality, and genetically deficient embryos display severe defects in their gastrointestinal vasculature, cerebellar neurons migration, cardiac ventricular septal closure, B-cell development, and hematopoietic BM colonization. ${ }^{47,48}$ The extensive consequences observed in different organs in the CXCL12/CXCR4 knock-out (KO) mice indicate that this axis is an essential component of differentiation of numerous tissues. Our findings indicate that MSCs are also likely to contribute to this differentiation.

The expression of CX3CR1 by BM-MSCs was an unexpected novel finding. Together with CXCL12-CXCR4, CX3CL1-CX3CR1 represented the major migration axis for BM-MSCs to tissue stimuli in vitro. CX3CL1 can exist either as a soluble protein or as a membrane-bound molecule. Both forms of CX3CL1 can mediate adhesion of cells expressing CX3CR1. This activity, together with its expression on endothelial cells after exposure to inflammatory mediators (tumor necrosis factor $\alpha$ [TNF- $\alpha$ ], IL- $1 \beta$, lipopolysaccharide [LPS], and interferon $\gamma$ [INF $\gamma]$ ), suggests that CX3CL1 might mediate adhesion of BM-MSCs to the endothelium during inflammation after tissue injury. Our findings with respect to CX3CR1 and CXCR4 receptor expression are consistent with a report showing that CXCL12-CXCR4 and CX3CL1-CX3CR1 interactions mediate the trafficking of transplanted MSCs in a rat model of left hypoglossal nerve injury. ${ }^{6}$ Both sets of findings are, however, inconsistent with a previous study showing that CCL2 in cerebral ischemic tissue promotes migration of infused MSCs to the site of injury. ${ }^{11}$ We did not find expression of the receptor for CCL2, CCR2, on human BM-MSCs, suggesting that CCL2-CCR2 interaction on MSCs may be specific for the rat model.

Although both CXCL12-CXCR4 and CX3CL1-CX3CR1 contributed to BM-MSC migration, it is unclear whether they operate synergistically or if they act in response to distinct stimuli. Redundancy for the CX3CL1-CX3CR1 migration axis is suggested by CX3CL1 gene disruption in the mouse. These mice do not have overt abnormalities in development, hematologic profile, lymphoid tissue structure, and response to inflammatory stimuli, ${ }^{49}$ but a specific study of MSCs in this model has not been performed. Our findings that other less well-characterized chemokine receptor axes such as CXCL16-CXCR6 could play a role in MSC migration also support redundancy in the determinants of MSC migration. CXCR6 is a newly characterized chemokine receptor that until now was described to be expressed selectively by subsets of memory/ effector T cells, ${ }^{50,51}$ natural killer (NK) cells, ${ }^{50} \mathrm{NKT}$ cells, ${ }^{52}$ and plasma cells. ${ }^{53}$ The CXCR6 ligand, CXCL16 was found to be a 
unique cell-bound $\mathrm{CXC}$ chemokine displaying some features of $\mathrm{CC}$ chemokines and a structure resembling that of CX3CL1. The unusual structural characters and cellular distribution of CXCR6 and its ligand, together with the fact that CXCR6-bearing T cells are enriched in inflamed tissues, such as rheumatoid arthritis joint lesions, atherosclerotic plaques, and chronic hepatitis $\mathrm{C}$-diseased liver, suggest that also CXCR6 could play a role in facilitating MSC localization in inflamed tissue. A small percentage of the MSCs analyzed expressed CCR1 or CCR7. Despite receptor expression on a small minority of cells, the corresponding chemokines CCL3, CCL19, and CCL21 were able to induce migration of a small number of BM-MSCs. Wynn et $\mathrm{al}^{45}$ also recently reported that cell surface levels of a chemokine receptor (CXCR4) on MSCs can be low, with large amounts found intracellularly. It is not clear whether the expression of chemokine receptors on a subgroup of MSCs identifies heterogeneous MSC populations or if this is an artifact of culture conditions.

Finally, the ability of pancreatic islets to attract BM-MSCs in vitro and in vivo speculates a potential role of these cells in $\beta$ cell replacement. We provide evidence that BM-MSCs are attracted by pancreatic islets in vitro and in vivo, that tissue MSCs are present in the pancreas, and that CXCL12 and CX3CL1 play a relevant role in migration. Several in vivo studies ${ }^{35-37}$ suggest that BM cells contribute to pancreatic $\beta$ cell regeneration, ${ }^{36}$ and it was proposed that the cell types in the BM responsible for pancreatic endocrine differentiation are MSCs. ${ }^{38,39}$ The role of BM-derived cells in $\beta$ cell replacement is controversial. Some evidence suggests the possibility that BM cells (including MSCs) differentiate into islet $\beta$ cells, ${ }^{36,38,39,54}$ and recently it has been suggested that human BM-derived stem cells can be induced to transdifferentiate into secretion competent insulin producing-cells and may serve as a potential autologous source for cell therapy (Lijun Yang, University of Florida, written personal communication, August 2004). Other reports have contradicted these findings, ${ }^{55,56}$ suggesting, in some cases, that BM cells could be "feeder" cells for islet differentiation, proliferation, and vascularization ${ }^{57}$ but do not differentiate into $\beta$ cells. ${ }^{37}$ Our findings do not address this issue.

In conclusion, we report that BM-MSCs migrate to a restricted set of chemokines in vitro. To our knowledge, this is the first comprehensive report of chemokine receptor expression on MSCs. Harnessing the migratory potential of MSCs by modulating their chemokine-chemokine receptor interaction may be a powerful way to enhance hematopoietic stem cell engraftment after transplantation, increase their ability to correct inherited disorders of bone or cartilage, or facilitate tissue repair in vivo.

\section{Acknowledgments}

The work was performed in the framework of the TelethonJuvenile Diabetes Research Foundation (JDRF) Center of Beta Cell Replacement at the S. Raffaele Scientific Institute. The support of Cesare Covino of the ALEMBIC (Advanced Light and Electron Microscopy BioImaging Center) service at the S. Raffaele Scientific Institute is gratefully acknowledged. We thank Mark Atkinson for critical reading of the manuscript.

\section{References}

1. Prockop DJ. Marrow stromal cells as stem cells for nonhematopoietic tissues. Science. 1997;276: 71-74.

2. Pittenger MF, Mackay AM, Beck SC, et al. Multilineage potential of adult human mesenchymal stem cells. Science. 1999;284:143-147.

3. Jiang $\mathrm{Y}$, Jahagirdar BN, Reinhardt RL, et al. Pluripotency of mesenchymal stem cells derived from adult marrow. Nature. 2002;418:41-49.

4. Asahara T, Kalka C, Isner JM. Stem cell therapy and gene transfer for regeneration. Gene Ther. 2000;7:451-457.

5. Bianco P, Robey PG. Stem cells in tissue engineering. Nature. 2001;414:118-121.

6. Ji JF, He BP, Dheen ST, Tay SS. Interactions of chemokines and chemokine receptors mediate the migration of mesenchymal stem cells to the impaired site in the brain after hypoglossal nerve injury. Stem Cells. 2004;22:415-427.

7. Munoz-Elias G, Marcus AJ, Coyne TM, Woodbury $\mathrm{D}$, Black IB. Adult bone marrow stromal cells in the embryonic brain: engraftment, migration, differentiation, and long-term survival. J Neurosci. 2004;24:4585-4595.

8. Barbash IM, Chouraqui P, Baron J, et al. Systemic delivery of bone marrow-derived mesenchymal stem cells to the infarcted myocardium: feasibility, cell migration, and body distribution. Circulation. 2003;108:863-868.

9. Annabi B, Lee YT, Turcotte S, et al. Hypoxia promotes murine bone-marrow-derived stromal cell migration and tube formation. Stem Cells. 2003; 21:337-347.

10. Hou LL, Zheng M, Wang DM, et al. [Migration and differentiation of human bone marrow mesenchymal stem cells in the rat brain]. Sheng Li Xue Bao. 2003;55:153-159.

11. Wang L, Li Y, Chen X, et al. MCP-1, MIP-1, IL-8 and ischemic cerebral tissue enhance human bone marrow stromal cell migration in interface culture. Hematology. 2002;7:113-117.
12. Lu D, Li Y, Wang L, Chen J, Mahmood A, Chopp M. Intraarterial administration of marrow stromal cells in a rat model of traumatic brain injury. J Neurotrauma. 2001;18:813-819.

13. Azizi SA, Stokes D, Augelli BJ, DiGirolamo C, Prockop DJ. Engraftment and migration of human bone marrow stromal cells implanted in the brains of albino rats-similarities to astrocyte grafts. Proc Natl Acad Sci U S A. 1998:95:3908-3913.

14. Campagnoli C, Roberts IA, Kumar S, Bennett PR, Bellantuono I, Fisk NM. Identification of mesenchymal stem/progenitor cells in human first-trimester fetal blood, liver, and bone marrow. Blood. 2001;98:2396-2402.

15. Liechty KW, MacKenzie TC, Shaaban AF, et al. Human mesenchymal stem cells engraft and demonstrate site-specific differentiation after in utero transplantation in sheep. Nat Med. 2000;6: 1282-1286.

16. Goodwin HS, Bicknese AR, Chien SN, Bogucki BD, Quinn CO, Wall DA. Multilineage differentiation activity by cells isolated from umbilical cord blood: expression of bone, fat, and neural markers. Biol Blood Marrow Transplant. 2001;7:581588.

17. Reyes M, Lund T, Lenvik T, Aguiar D, Koodie L, Verfaillie CM. Purification and ex vivo expansion of postnatal human marrow mesodermal progenitor cells. Blood. 2001;98:2615-2625.

18. Kuznetsov SA, Mankani MH, Gronthos S, Satomura K, Bianco P, Robey PG. Circulating skeletal stem cells. J Cell Biol. 2001;153:1133-1140.

19. Mahmud N, Pang W, Cobbs $C$, et al. Studies of the route of administration and role of conditioning with radiation on unrelated allogeneic mismatched mesenchymal stem cell engraftment in a nonhuman primate model. Exp Hematol. 2004; 32:494-501.

20. Rombouts WJ, Ploemacher RE. Primary murine MSC show highly efficient homing to the bone marrow but lose homing ability following culture. Leukemia. 2003:17:160-170.
21. Agematsu K, Nakahori Y. Recipient origin of bone marrow-derived fibroblastic stromal cells during all periods following bone marrow transplantation in humans. Br J Haematol. 1991;79:359-365.

22. Stute N, Fehse B, Schroder J, et al. Human mesenchymal stem cells are not of donor origin in patients with severe aplastic anemia who underwent sex-mismatched allogeneic bone marrow transplant. J Hematother Stem Cell Res. 2002;11:977984.

23. Awaya N, Rupert K, Bryant E, Torok-Storb B. Failure of adult marrow-derived stem cells to generate marrow stroma after successful hematopoietic stem cell transplantation. Exp Hematol. 2002; 30:937-942.

24. Simmons PJ, Przepiorka D, Thomas ED, TorokStorb B. Host origin of marrow stromal cells following allogeneic bone marrow transplantation. Nature. 1987;328:429-432.

25. Tanaka J, Kasai M, Imamura M, et al. Evaluation of mixed chimaerism and origin of bone marrow derived fibroblastoid cells after allogeneic bone marrow transplantation. Br J Haematol. 1994;86: 436-438.

26. Cilloni D, Carlo-Stella C, Falzetti F, et al. Limited engraftment capacity of bone marrow-derived mesenchymal cells following T-cell-depleted hematopoietic stem cell transplantation. Blood. 2000;96:3637-3643.

27. Morigi M, Imberti B, Zoja C, et al. Mesenchymal stem cells are renotropic, helping to repair the kidney and improve function in acute renal failure. J Am Soc Nephrol. 2004;15:1794-1804.

28. Murphy JM, Fink DJ, Hunziker EB, Barry FP. Stem cell therapy in a caprine model of osteoarthritis. Arthritis Rheum. 2003;48:3464-3474.

29. Shake JG, Gruber PJ, Baumgartner WA, et al. Mesenchymal stem cell implantation in a swine myocardial infarct model: engraftment and functional effects [discussion Ann Thorac Surg. 2002; 73:1926]. Ann Thorac Surg. 2002;73:1919-1925. 
30. Barry FP, Murphy JM. Mesenchymal stem cells: clinical applications and biological characterization. Int J Biochem Cell Biol. 2004;36:568-584.

31. Barry FP. Biology and clinical applications of mesenchymal stem cells. Birth Defects Res Part C Embryo Today. 2003;69:250-256.

32. Piemonti L, Leone BE, Nano R, et al. Human pancreatic islets produce and secrete MCP-1/ CCL2: relevance in human islet transplantation. Diabetes. 2002;51:55-65

33. Sozzani S, Luini W, Borsatti A, et al. Receptor expression and responsiveness of human dendritic cells to a defined set of CC and CXC chemokines. J Immunol. 1997; 159:1993-2000.

34. Bertuzzi F, Davalli AM, Nano R, et al. Mechanisms of coordination of $\mathrm{Ca} 2+$ signals in pancreatic islet cells. Diabetes. 1999;48:1971-1978.

35. Zorina TD, Subbotin VM, Bertera S, et al. Recovery of the endogenous beta cell function in the NOD model of autoimmune diabetes. Stem Cells. 2003;21:377-388.

36. lanus A, Holz GG, Theise ND, Hussain MA. In vivo derivation of glucose-competent pancreatic endocrine cells from bone marrow without evidence of cell fusion. J Clin Invest. 2003;111:843850.

37. Hess D, Li L, Martin M, et al. Bone marrowderived stem cells initiate pancreatic regeneration. Nat Biotechnol. 2003;21:763-770.

38. Tang DQ, Cao LZ, Burkhardt BR, et al. In vivo and in vitro characterization of insulin-producing cells obtained from murine bone marrow. Diabetes. 2004;53:1721-1732.

39. Kodama S, Kuhtreiber W, Fujimura S, Dale EA, Faustman $\mathrm{DL}$. Islet regeneration during the reversal of autoimmune diabetes in NOD mice. Science. 2003;302:1223-1227.

40. Friedenstein AJ. Marrow stromal fibroblasts. Calcif Tissue Int. 1995;56(suppl 1):S17.
41. Goshima J, Goldberg VM, Caplan Al. The osteogenic potential of culture-expanded rat marrow mesenchymal cells assayed in vivo in calcium phosphate ceramic blocks. Clin Orthop Relat Res. 1991;262:298-311.

42. Deschaseaux F, Gindraux F, Saadi R, Obert L, Chalmers D, Herve P. Direct selection of human bone marrow mesenchymal stem cells using an anti-CD49a antibody reveals their CD45med, low phenotype. Br J Haematol. 2003;122:506-517.

43. Peled A, Petit I, Kollet O, et al. Dependence of human stem cell engraftment and repopulation of NOD/SCID mice on CXCR4. Science. 1999;283: 845-848.

44. Muller A, Homey B, Soto H, et al. Involvement of chemokine receptors in breast cancer metastasis. Nature. 2001;410:50-56.

45. Wynn RF, Hart CA, Corradi-Perini C, et al. A small proportion of mesenchymal stem cells strongly expresses functionally active CXCR4 receptor capable of promoting migration to bone marrow. Prepublished on July 13,2004 , as DOI 10.1182/ blood-2004-02-0526. (Now available as Blood. 2004;104:2643-2645).

46. McGrath KE, Koniski AD, Maltby KM, McGann JK, Palis J. Embryonic expression and function of the chemokine SDF-1 and its receptor, CXCR4. Dev Biol. 1999;213:442-456.

47. Ma Q, Jones D, Borghesani PR, et al. Impaired B-lymphopoiesis, myelopoiesis, and derailed cerebellar neuron migration in CXCR4- and SDF-1deficient mice. Proc Natl Acad Sci U S A. 1998; 95:9448-9453.

48. Tachibana K, Hirota S, lizasa H, et al. The chemokine receptor CXCR4 is essential for vascularization of the gastrointestinal tract. Nature. 1998; 393:591-594.

49. Cook DN, Chen SC, Sullivan LM, et al. Generation and analysis of mice lacking the chemokine fractalkine. Mol Cell Biol. 2001;21:3159-3165.
50. Unutmaz D, Xiang W, Sunshine MJ, Campbell J Butcher E, Littman DR. The primate lentiviral receptor Bonzo/STRL33 is coordinately regulated with CCR5 and its expression pattern is conserved between human and mouse. J Immunol. 2000;165:3284-3292.

51. Kim CH, Kunkel EJ, Boisvert J, et al. Bonzo/ CXCR6 expression defines type 1-polarized Tcell subsets with extralymphoid tissue homing potential. J Clin Invest. 2001;107:595-601.

52. Kim CH, Johnston B, Butcher EC. Trafficking machinery of NKT cells: shared and differential chemokine receptor expression among $\mathrm{V}$ alpha 24(+)V beta 11(+) NKT cell subsets with distinct cytokine-producing capacity. Blood. 2002;100:1116.

53. Nakayama T, Hieshima K, Izawa D, Tatsumi $Y$ Kanamaru A, Yoshie O. Cutting edge: profile of chemokine receptor expression on human plasma cells accounts for their efficient recruitment to target tissues. J Immunol. 2003;170: 1136-1140.

54. Oh SH, Muzzonigro TM, Bae SH, LaPlante JM, Hatch HM, Petersen BE. Adult bone marrowderived cells trans-differentiating into insulin-producing cells for the treatment of type I diabetes. Lab Invest. 2004;84:607-617.

55. Dor Y, Brown J, Martinez OI, Melton DA. Adult pancreatic beta-cells are formed by self-duplication rather than stem-cell differentiation. Nature. 2004;429:41-46.

56. Lechner A, Yang YG, Blacken RA, Wang L, Nolan AL, Habener JF. No evidence for significant transdifferentiation of bone marrow into pancreatic beta-cells in vivo. Diabetes. 2004;53:616-623.

57. Mathews V, Hanson PT, Ford E, Fujita J, Polonsky KS, Graubert TA. Recruitment of bone marrow-derived endothelial cells to sites of pancreatic beta-cell injury. Diabetes. 2004;53:91-98. 